\title{
CRIMINAL LAW: COMMITMENT AND RELEASE OF CRIMINAL DEFENDANTS ACQUITTED BY REASON OF INSANITY
}

$\mathrm{W}$ HEN THE DEFENDANT in a criminal case is found not guilty by reason of insanity, ${ }^{1}$ a proper solution to his disposition seeks to satisfy three possibly conflicting considerations. Society demands that dangerous persons be prevented from causing further harm; legal tradition demands that liberty be taken away only by due process of law; modern scientific knowledge demands that the psychiatric aspects of commitment and release be given increased emphasis.

A District of Columbia statute ${ }^{2}$ provides that a defendant acquitted solely on the ground of insanity at the time of the crime shall be indefinitely committed to a public hospital for the inentally ill without a further hearing. The'act provides for a release procedure which is initiated by the hospital superintendent's certification that the former defendant has recovered his sanity and will not be dangerous in the reasonable future. $^{3}$ The statute also stipulates that the confined person has the right of habeas corpus.

Although the automatic commitment provision of this statute seems to accord with the wishes of both the psychiatric profession and the community at large, ${ }^{4}$ the question of its impingement on the constitutional rights of the person confined was raised in a recent case, Ragsdale v. Overholser. $\mathrm{D}$, tried on a robbery charge, was found not guilty by

\footnotetext{
1 The term "insanity" is used in this note when paraphrasing language of statutes or judicial opinions, but the word has little medical meaning. Modern psychiatrists unanimously prefer the term "mental illness" when speaking categorically. WEIHOFEN, Mental Disorder as a Criminal Defense 5 (1954); Weihofen, The Definition of Mental Illness, 2 I OHro ST. L.J. I (1960).

${ }^{2}$ D.C. Code ANN. $\$ 24-301$ (Supp. 1958).

${ }^{3}$ The court, in its discretion, may hold a hearing on the mental condition of the petitioner. D.C. CODE ANN. \& 24-30I(d) (Supp. 1958).

' Prior to the case of Durham v. United States, 214 F.2d 862 (D.C. Cir. 1954), the statute provided for commitment at the discretion of the trial judge. This decision thoroughly displeased certain members of Congress and a committee investigated the result of the Durham case and other recent decisions in the area of criminal insanity. Despite the admitted fact that no case could be found in which the acquitted defendant had not been committed, the committee concluded, in agreement with psychiatric testimony, that "the public is entitled to know that . . . such person shall be given a period of hospitalization and treatment to guard against eminent recurrence of some criminal act by that person." H.R. REP. No. 892, 84th Cong., Ist Sess. I3 (1955).

${ }_{28}$ I F.2d 943 (D.C. Cir. 1960 ).
} 
reason of insanity and was automatically confined under the above statute. In petitioning for a writ of habeas corpus, $\mathrm{D}$ alternately pleaded that his automatic commitment was unconstitutional or that if he were correctly confined, he had recovered. On the commitment issue, he argued that since the prosecution has the burden of proof on the issue of insanity once raised, ${ }^{6}$ an acquittal by reason of insanity means only that the prosecution has failed to establish beyond a reasonable doubt that the defendant was sane at the time of the crime. D further maintained that an affirmative finding of his insanity at the time of the trial was a due process prerequisite to his indefinite confinement. ${ }^{7}$ The District of Columbia District Court rejected this argument and the Court of Appeals affirmed, finding a "rational connection" between the jury's verdict and D's commitment. ${ }^{8}$ As to D's allegations of recovery, the Court of Appeals increased the necessary quantum of proof, ruling that a person of this class must show beyond a reasonable doubt that he has recovered his sanity and will not be dangerous to himself or to the public. The court held that $\mathrm{D}$ had not sustained this burden. ${ }^{9}$

Similar statutes ${ }^{10}$ prescribing automatic indefinite commitment previously have been upheld, ${ }^{11}$ principally on two rationales. The first is

\footnotetext{
${ }^{6}$ In a large number of states the defendant has the burden of persuasion on the issue of insanity. A verdict of not guilty by reason of insanity in such a jurisdiction aneans that the defendant had sustained his burden by a preponderance of the evidence, $I$ Wharton, Criminal Evidence \& 30 (12th ed. 1955); 9 Wigmore, Evidence $\$ 2501$ ( $3 \mathrm{~d}$ ed. 1940) and in one state beyond a reasonable doubt. State v. Leland, 19o Ore. 598,227 P.2d 785 (195I); aff'd 343 U.S. 790 (1952). However, in all federal courts the defendant has only the burden of going forward with evidence of insanity. Davis v. United States, 160 U.S. 469 (1895). More significant is the fact that in the District of Columbia, the defendant presently need only introduce "some evidence" of insanity to warrant an instruction on this issue, Tatum v. United States, 109 F.2d 612 (D.C. Cir. 195I), in contrast to a previous requirement of "evidence sufficient to create a reasonable doubt as to his mental capacity." Holloway v. United States 148 F.2d 665,666 (D.C. Cir. 1945).

${ }^{7}$ Even if the defendant had been found insane at the time of the crime, the test of whether he should now be confined is whether he is dangerous to himself and to others at the present time. See Annot., 158 A.L.R. 1220, 1225 (1945).

${ }^{8}$ Ragsdalc v. Overholser, 281 F.2d 943,948 (D.C. Cir. 1960).

- Judge Fahy, in concurring in the result, expressed the opinion that the burden of proof should not be increased at the present time. Id. at 950 .

${ }^{10}$ Eight other jurisdictions presently have automatic commitment statutes. CoLo. Rev. Stat. ANn. § 39-8-4 (1953); GA. CODE ANN. § 27-1503 (1953); KAN. Gen. Stat. ANn. § 62-1532 (1949); MinN. Stat. AnN. § 631.19 (1957); NEb. Rev. Stat. $\S$ 29-2203 (I956); NEV. REv. STAT. § 175.445 (I960); OHIO REv. CODE ANN. § 2945.39 (Page I953); Wis. STAT. \& 957.1 I (1957).

${ }_{11}$ People v. D'Angelo, $x_{3}$ Cal. 2d 203, 88 P.2d 708 (1939); Hodison v. Rogers, 137 Kan. 950, 22 P.2d 491 (I933); People ex rel. Peabody v. Chanler, I33 App. Div. I59,
} 
based on a presumption that the insanity continues from the time of the crime until that of the trial.12 The use of this presumption can be sustained if there is a rational connection between the jury's verdict and the ultimate fact presumed-that defendant was insane at the time of the trial. ${ }^{13}$ This connection, however, is not present in the District of Columbia. In that jurisdiction a jury may not be instructed to make an affirmative finding of insanity at the time of the crime. ${ }^{14}$ The presumption is also weakened because there may be an extensive lapse of time between the crime and the trial. ${ }^{15}$ Furthermore, the fact that the defendant was mentally competent to stand trial tends to negate the assumption that immediately following the trial his mental condition requires prompt indefinite confinement. ${ }^{16}$

The Court of Appeals in Ragsdale seemed somewhat responsive to the weaknesses of the "rational connection" argument and relied on the second traditional rationale, that automatic commitment is constitutional because $\mathrm{D}$ can question the legality of his detention by habeas corpus. ${ }^{17}$ An argument that sustains original confinement of dubious validity by

II7 N.Y. Supp. 322, aff'd 196 N.Y. 525, 89 N.E. I109 (1909); In re Brown, 39 Wash. 160, 81 Pac. 552 (1905); State v. Saffron, 146 Wash. 202, 262 Pac. 970 (1927); contra, Brown v. Urquhart, 139 Fed. 846 (C.C.W.D. Wash. 1905), revd on other grounds (205 U.S. 179 (1907); Morgan v. State, 179 Ind. 300, IoI N.E. 6 (1913). It has been held that even though the defendant was declared sane just prior to the criminal trial, he may be automatically committed to an insane asylum for observation. State v. Burris, I69 La. 520,535 , 125 So. 580,585 (1929). See generally Annot, 145 A.L.R. 892 (1943). In addition to the two principal arguments, support has also been found in the contention that the criminal trial and the verdict are the equivalent of civil commitment proceedings, In re Clark, $86 \mathrm{Kan}$. 539, I2I Pac. 492 ( 1912$)$, and in the argument that the accused knows he will be automatically committed if he pleads insanity. People ex rel. Peabody v. Baker, 59 Misc. 359, IIO N.Y. Supp. 848 (1908).

${ }^{12}$ In re Clark, supra note 11. See generally Annot., 27 A.L.R.2d 125 (1953).

${ }^{13}$ Tot v. United States, 3 I9 U.S. 463 (1943); see generally CoRwIN, THE CONSTITUTION OF THE UNITED STATES OF AMERICA I094 (1952).

${ }^{14}$ Carter v. United States, 252 F.2d 608 (D.C. Cir. 1957).

${ }^{15}$ Fielding v. United States, 251 F.2d 878 (D.C. Cir. 1957) (two years and nine months lapse); Douglas v. United States, 239 F.2d 52 (D.C. Cir. 1956) (two years lapse).

${ }^{16}$ It is possible that a person's mental condition would be such that he could stand trial and yet require hospitalization for a dangerous mental illness, as the legal tests for the defendant's mental condition at the two times are different. Overholser v. Leach, 257 F.2d 667,670 (D.C. Cir. 1958). Nevertheless, his mental condition at these times should be determined by medical examination rather than broadly presumed. See Underwood v. People, 32 Mich. I (I875).

${ }^{17}$ People v. Dubina, 304 Mich. 363,8 N.W.2d 99, cert. denied $3 \times 9$ U.S. 766 (1943). 
pointing to a means of later release does not seem sound, ${ }^{18}$ particularly when the petitioner's burden of proof for release is simultaneously increased. ${ }^{10}$ The vital issue in these cases is whether the petitioner should have the burden of proof at the release hearing.

When a defendant is acquitted by reason of insanity, considerations of public safety support automatic commitment for a period reasonably necessary for a thorough psychiatric examination. Following this period, due process would seem to require a hearing and an affirmative finding of a dangerous mental condition at that time if $\mathrm{D}$ 's detention is to be continued. ${ }^{20}$ It has been argued that because the petitioner has been acquitted of the only charge against him, the burden of proving a present dangerous mental condition should be on the committing authorities. $^{21}$ Even assuming the burden may be placed on the person confined,

${ }^{18}$ The Supreme Court has definitely sanctioned indefinite confinement in a mental institution for those persons psychiatrically determined to be dangerously mentally ill, Greenwood v. United States, 350 U.S. 366 (1956), but indefinite confinement based on a presumption is another matter. It was earlier thought that the right to petition for discharge would reconcile the lack of an original hearing with due process, Ekiu v. United States, 142 U.S. 65I (1892); FREUND, POLICE POWER, § 255 (1904), but perhaps now an initial invalid confinement will entitle a petitioner to an order of discharge so far as his present confinement is concerned, even though he might still be mentally ill. See Barry v. Hall, 98 F.2d 222, 229 (D.C. Cir. 1938).

${ }^{10}$ Ragsdale is the only decision found that has announced such a heavy burden.

${ }^{20}$ Simon v. Craft, 182 U.S. 427 (1901); Barry v. Hall 98 F.2d 222 (D.C. Cir. 1938). Judge Fahy, in a concurring opinion in Ragsdale, felt that if the person confined did not respond to treatment within a reasonable time, then civil commitment proceedings would be necessary. Ragsdale v. Overholser, 28 i F.2d 943, 949 (D.C. Cir. x960).

${ }^{21}$ Brown v. Urquhart, 139 Fed. 846 (C.C.W.D. Wash. 1905), rev'd on other grounds 205 U.S. 179 (1907). But see Overholser v. Leach, 257 F.2d 667 (D.C. Cir. 1958). Civil commitment proceedings have been argued to be particularly necessary in the District of Columbia now, as the prosecution has started introducing evidence of mental illness in the criminal trial over the defendant's objections. Halleck, The Insanity Defense in the District of Columbia-A Legal Lorelei. 49 GEo. L.J. 294 (1960).

A more fundamental argument is that having a criminal trial in addition to a second hearing or trial to determine the present condition of the accused is very undesirable, as the criminal trial is a waste of time if $D$ is to be committed to a mental institution in any event, Weihofen, Institutional Treatment of Persons Acquitted by Reason of Insanity, ${ }_{3} 8$ TEX L.R. 849 (1960), and the police methods of confinement have a deleterious effect on the therapeutic treatment to be given the patient. LiNDNER \& Seliger, Correctional. Psychology, 254 (1947). The above reasons are among those underlying the philosophy of the Massachusetts Briggs Law, MAss. ANN. Laws ch. $123 \S 100 A$ (1957), which provides for a routine psychiatric examination before the trial of all persons charged with certain offenses. Such a plan has the merit of detecting mental illness by trained personnel. See Overholser, The Briggs Law of Massachusetts: $A$ Review and an Appraisal, $25 \mathrm{~J}$. Crim. L. \& Criminology 859 (1935). 
his burden of proof certainly should not exceed that of a preponderance of the evidence. ${ }^{22}$

The aspects of Ragsdale dealing with release raise independent policy questions as to the procedures involved. ${ }^{23}$ The release procedure of the statute was intended by Congress to be initiated only by the mental hospital superintendent's certification that the confined person has recovered and is no longer dangerous, ${ }^{24}$ but a provision for habeas corpus was believed to be a constitutional necessity. ${ }^{25}$ The right of habeas corpus has been somewhat abused in recent years by unceasing petitions by the same persons. ${ }^{26}$ As a prior hearing on recovery from mental illness is not res judicata, another petition may be presented immediately following the previous hearing. ${ }^{27}$ The recurring petition problem has been partially alleviated by the denial of obviously defective petitions. ${ }^{28}$ The court in Ragsdale may have been subtly addressing itself to this problem of recurring petitions when it increased the petitioner's burden of proof..$^{29}$ Under common law habeas corpus doctrine the certificate of the superintendent is not required for release, but some statutes make

${ }^{22}$ Most jurisdictions place the burden of persuasion on the person desiring release. WEIHOFEN, op. cit. supra note 1 , at 382 .

${ }^{23}$ "The procedure for release of insane persons accused, or acquitted, of crime is unquestionably the weakest link in the entire chain of legal treatment of the problem." Glueck, Mental Disorder and the Criminal LaW, $39 x$ ( $x 927$ ).

${ }^{24}$ It was felt that whether the confined person had recovered was primarily a psychiatric question. H.R. REP. No. 892, 84th Cong., Ist Sess. I 3 (1955).

${ }_{25}$ See In re Opinion of the Justices, $15 x$ Me. I, $x 17$ A.2d 53 (1955); Underwood v. People, 32 Mich. x (1875); State ex rel. Fuller v. Mullinax, 269 S.W.2d 72 (Mo. 1954); In re Boyett, $\times 36$ N.C. $4 \times 5,48$ S.E. 789 (1904).

${ }^{20} \mathrm{~A}$ marked increase in habeas corpus petitions has been seen following Walker v. Johnston, $3 \times 2$ U.S. 275 (194I) in which the Supreme Court made clear that the right of habeas corpus was not to be taken lightly by the federal judiciary A few persons submit a large number of applications, and the majority of applications are repeater petitions. Speck, Statistics on Federal Habeas Corpus, 10 OHIO ST. L.J. 337 (1949); see generally, Parker, Limiting the Abuse of Habeas Corpus, 8 F.R.D. I71 (1948); Goodman, Use and Abuse of the Writ of Habeas Corpus, 7 F.R.D. 313 (1947).

${ }^{27}$ Salinger v. Loisel, 265 U.S. 224 ( (924) $^{2}$ ). The only reasons for which a petition may be denied without a hearing or without issuing an order to show cause directed to determine why the petition should not be granted are: (I) even if what is alleged is true, there can be no relief granted; (2) the request has come too soon after commitment; (3) the petitioner filed as a pauper and he was not a pauper. Tatem v. United States, 275 F.2d 894, 896 (D.C. Cir. 1960 ).

${ }^{28}$ Stewart v. Overholser, I86 F.2d 339 (D.C. Cir. 1950); Dorsey v. Gill, 148 F.2d 857 (D.C. Cir. ₹945).

${ }_{20}$ The court's endeavor seems to be to reasonably quell the ever-growing volume of haebas corpus petitions and yet heed the mandate of Walker v. Johnston, $3 \pm 2$ U.S. 275 (194I). 
the superintendent's approval an unwavering prerequisite to release. ${ }^{30}$ It is arguable that Ragsdale is a judicial revision of the District of Columbia statute to this latter effect. ${ }^{31}$ While the court may have felt the additional quantum of proof was necessary in view of a district court decision in a parallel case, ${ }^{32}$ the decisions of the District of Columbia District Court do not reflect indifference to public safety..$^{33}$

Habeas corpus under this statute is designed to test the judgment of the hospital authorities, who are prone to assume a protective role toward society with respect to the release of these persons. ${ }^{34}$ Yet, considering the adversary procedure that is followed, the remedy would seem to be either unsatisfactory from the public's viewpoint or meaningless to the petitioner. If the petitioner can afford to hire his own psy-

${ }^{30}$ CAL. PEN. CODE $\$ 1026$ (a) (application only at yearly intervals); IND. ANN. STAT. $\$$ 9-1705 (1933) (first application only after two years, subsequent applications at five-year intervals); MAss. ANN. Laws ch. 123, $§$ 101 (1957) (acquitted murderers discharged only by consent of governor); UTAH CODE ANN. \$ 77-24-16 (1953) (application only at yearly intervals); WASH. REv. CODE $\$ 10.76 .070$ (1957) (must have approval of superintendent to petition the court); WIS STAT. ANN. \& 292.02 (195I) (habeas corpus not available to acquitted criminals). See GLUECK, op. cit. sttpra note 23, at 491 . Indeternninate and possibly permanent confinement has been strongly advocated, but only for those deemed incurably mentally ill. Bigcs, THE GUILTY MIND 194 (1955).

${ }^{31}$ In accord with the theory that the question of recovery is primarily a psychintric one, it has been argued that a confined person of this class should not be released until psychiatrists certify that he has recovered from his mental illness and is no longer dangerous. GLUECK, op. cit. supra note 23, at 397. Some writers feel that the psychiatrists alone should be the judge of the readiness for release of such persons, Szazs, Givil Liberties and Mental Illness-Some Observations on the Case of Miss Editl L. Hough, 131 J. OF Nervous and Mental Diseases 58 (1960). But c.f. Goldstein and Katz, Dangerousness and Mental Illness, Some Observations on the Decision to Release Persons Acquitted by Reason of Insanity, 70 YALE L.J. 225 (1960).

For an excellent argument for release to be determined by a commission, see Comment, Releasing Criminal Defendants Acquited and Committed Because of Insanity: The Need for Balanced Administration, 68 YALE L.J. 293 (1958). But of. GluecK, op. cit. supra note 23 , at $44 \mathrm{I}$.

${ }^{32}$ Overholser v. Russell, 283 F.2d 195 (D.C. Cir. 1960). This case is the only recent case found in which the district court released a confined person without the superintendent's approval. The case is distinguishable, however, in that the criminal propensity involved (forgery) was of a non-violent nature and the district court had had no previous ruling that the same stringent standards for release were to be applied in all cases under the statute.

${ }^{33}$ Petitioners in the District of Columbia had found the previous burden of proof for release quite an imposing barrier without the superintendent's approval. One petition failed which was approved by every staff psychintrist connected with the confined person. In $r e$ Rosenfield, 157 F. Supp. 18 (D.D.C. 1957), aff'd 262 F.2d 34 (D.C. Cir. 1958); Comment, Releasing Criminal Defendants Acquitted and Committed Because of Insanity: The Need for Balanced Administration, 68 YALE L.J. 293 (1958).

${ }^{34}$ Weihofen, supra note 21 , at 866. 
chiatrist to rebut the testimony of hospital authorities, the layman judge is called upon to decide between conflicting scientific opinion. If the petitioner is a pauper, there is no real contest.

The result of Ragsdale is that persons of a mental condition undetermined either judicially or medically are committed for an indefinite period with an extremely heavy burden of proof for release..$^{35}$ In addition, the habeas corpus hearing does not substantially enlighten the judge or offer a valid remedy to the person confined. More extensive use of the trial court's discretion to have the petitioner examined by neutral government psychiatrists would seem to be one method of fulfilling the purpose of the habeas corpus remedy without further legislation, at least in the District of Columbia. ${ }^{36}$ This would provide a better balance between traditional notions of due process and uncontrolled power in the hands of psychiatric staffs of mental institutions.

\footnotetext{
${ }^{35} \mathrm{~A}$ by-product of Ragsdale will doubtless be the obsolescence of the plea of insanity in noncapital cases in the District of Columbia. The statute has already been changed to make it more difficult for the accused to get a mental examination. D.C. CODE ANN. § 24-30I (a) (Supp. 1958). The judge now can order an examination only when a prima facie case of inental illness is presented. See Comment, Insanity and the Criminal Law in the District of Columbia, 44 GEo. L.J. 489 (1956). Such a change reflects a desire to inflict punishment on the individual and not let him "get off" with an insanity. plea. A better reasoned statute would concern itself with the individual's social dangerousness rather than his moral culpability, and would thus concentrate on detecting mental illness among criminals, as penal confinement is certainly not a deterrent to crimes caused by mental illness. See WErHOFEN, THE URGE TO PUNISH 136 (1956); BrGGs, op. cit. supra note 30, at I64, I92; GLUECK, op. cit. suppra note 23, at 55; Glueck, Psychiatric Examination of Persons Accused of Crime, 36 YALE L.J. 632 (1927).

${ }^{30}$ The Court of Appeals has made it clear that the district court has the authority to call on the Commission of Mental Health for assistance in this regard, but this plan does not seem to have been often advocated by counsel. De Marcos v. Overholser, 137 F.2d 698 (D.C. Cir.), cert. denied 320 U.S. 785 (1943). The court regarded such a plan as part of a nationwide movement to give courts the assistance of unbiased experts. See Dession, Psychiatry and the Conditioning of Criminal Justice, 47 YALE L.J. 3 I 9 (1938).
} 